\title{
PENERAPAN MODEL PEMBELAJARAN VAN HIELE UNTUK MENINGKATKAN KEMAMPUAN KOMUNIKASI SISWA SMP
}

\author{
${ }^{1)}$ Siti Chotimah, ${ }^{2)}$ Hamidah \\ ${ }^{1)}$ chotie_pis@yahoo.com, ${ }^{2)}$ shiroimida@gmail.com \\ ${ }^{1,2)}$ STKIP SILIWANGI BANDUNG
}

\begin{abstract}
ABSTRAK
Latarbelakang penelitian ini yaitu menerapkan keterampilan dalam geometri yang mampu mendukung pamahaman siswa terhadap ilmu lain dalam matematika seperti ilmu menghitung, mengukur, dan lainlain. Namun kenyataannya, geometri merupakan salah satu pokok bahasan yang kebanyakan tidak diminati siswa. Kemampuan komunikasi matematis merupakan salah satu kemampuan yang diperlukan dalam memahami geometri. Terdapat lima fase berpikir dalam model Van Hiele yang memberi pengaruh positif terhadap kemampuan koneksi matematis siswa. Penelitian ini merupakan eksperimen dengan disain pretest-postest control group design. Populasi dalam penelitian ini adalah seluruh siswa SMP kelas VII di Tirtayasa, sedangkan sampelnya adalah siswa kelas VII dari salah satu SMP di Tirtayasa yang ditetapkan secara purposive dan dipilih dua kelas VII secara acak dari kelas VII yang ada. Data hasil penelitian akan dianalisis dengan menggunakan uji statistik t, uji koefisien kontingensi dan uji dengan statistik chi kuadrat. Berdasarkan analisis data kuantitatif, diperoleh kesimpulan bahwa kemampuan komunikasi matemat is siswa SMP yang memperoleh model pembelajaran Van Hiele lebih baik daripada yang memperoleh pembelajaran biasa.
\end{abstract}

Kata Kunci: komunikasi matematis dan pembelajaran Van Hiele

\begin{abstract}
Background of this research is to apply skills in geometry that can support students' understanding of other disciplines in mathematics such as arithmatic, measuring, and others. But reality, geometry is one subject that most students are not interested. Mathematical communication skills is one of the capabilities required to understand the geometry. There are five phases of the model of Van Hiele think that gave a positive influence on students' mathematical connection capabilities. This research is an experimental design with pretest-posttest control group design. The population in this study are all secondary school students in grade seventh Tirtayasa, while the sample is a seventh grade student from one of the first secondary school in Tirtayasa set purposively and have two grade 7 at radom from the existing seven class. Data were analyzed using $t$ statistical test, test and test kontingansi coefficient with chi square statistic. Based on the analysis of quantitative data, we concluded that the mathematical ability that communication skills of high school students first to acquire Van Hiele learning model is better that the usual learning gain.
\end{abstract}

Keywords: communication and learning mathematical Van Hiele.

\section{PENDAHULUAN}

Matematika merupakan salah satu pelajaran yang erat kaitannya dengan kehidupan nyata. Tidak sedikit hal maupun masalah yang ada disekeliling kita memerlukan ilmu matematika. Geometri merupakan salah satu cabang ilmu matematika yang paling mudah dikaitkan dengan kehidupan nyata. Dengan demikian seharusnya cabang ilmu ini relatif mudah disampaikan oleh guru dan dipahami oleh siswa. Namun kenyataannya, geometri merupakan salah satu pokok bahasan yang kebanyakan tidak minati oleh siswa. Wardhani \& Rumiati (Safrina, 2014) menjelaskan bahwa hanya $20 \%$ siswa Indonesia dapat menjawab dengan benar salah satu soal pemecahan masalah geometri mengenai konsep keliling persegi, persegi panjang dan jajargenjang.

Dalam NCTM 1999 dan KTSP 2006 (Sumarmo, 2012) disebutkan bahwa komunikasi matematik merupakan kemampuan matematik yang esensial, antara lain dapat mengkomunikasikan gagasan dengan simbol, tabel diagram, atau ekspresi matematik untuk memperjelas keadaan atau masalah, dan memiliki sifat menghargai kegunaan matematika dalam kehidupan, sikap rasa ingin tahu, perhatian dan minat dalam mempelajari matematika, serta sikap ulet dan percaya diri dalam pemecahan masalah. Sumarmo (2012) 
mengemukakan, pengembangan kemampuan komunikasi matematik sesuai dengan hakekat matematika sebagai bahasa simbol yang efisien, padat makna, memiliki sifat keteraturan yang indah dan kemampuan analisis kuantitatif, bersifat universal, dan dapat dipahami oleh setiap orang kapan dan dimana saja, dan membantu menghasilkan model matematika yang diperlukan dalam pemecahan masalah berbagai cabang ilmu pengetahuan dan masalah kehidupan sehari-hari.

Seseorang yang memiliki kemampuan komunikasi mampu menggambarkan konsep matematis dalam sebuah permasalahan matematis dengan cara membangun sebuah model matematika. Sumarmo (2012) menyebutkan bahwa salah satu indikator kemampuan komunikasi adalah menyusun konjektur, menyusun argument, merumuskan definisi dan generalisasi.

Namun demikian, pada kenyataan di lapangan banyak dijumpai gaya mengajar guru yang belum maksimal sehingga hasil belajar siswa belum efisien. Hasil penelitian Suryadi (2004) menunjukkan bahwa pembelajaran matematika pada umumnya masih berfokus pada pengembangan kemampuan berpikir tahap rendah yang prosedural. Usiskin (1982) menyebutkan bahwa salah satu faktor yang memberi pengaruh besar terhadap kemampuan matematika siswa adalah kualitas dari pembelajaran matematika. Untuk itu perlu satu pembelajaran yang berkualitas yang mampu memberi pengaruh besar terhadap kemampuan matematik khususnya kemampuan komunikasi matematis siswa. Salah satu pembelajaran tersebut adalah model pembelajaran Van Hiele.

Terdapat lima fase berpikir dalam model pembelajaran Van Hiele yaitu fase pengenalan, analisis, pengurutan, deduksi, dan akurasi. Burger (1986) menyebutkan pembelajaran geometri Van Hiele mampu mengajak siswa untuk mengeksplor kemampuannya dalam melihat beberapa karakteristik yang berkaitan dengan matematika khususnya geometri serta mengajak siswa untuk berpartisipasi aktif secara rutin selama proses pembelajaran. Fase-fase dalam model pembelajaran Van Hiele mampu memberi kontribusi terhadap kemampuan komunikasi.

Sejalan dengan latar belakang tersebut, penelitian ini mengambil judul "Pengaruh Model Pembelajaran Van Hiele untuk Meningkatkan Kemampuan Komunikasi Matematis Siswa SMP”.
Secara umum rumusan masalah dalam penelitian ini adalah:

Apakah kemampuan komunikasi matematis siswa SMP yang memperoleh model pembelajaran Van Hiele lebih baik daripada yang memperoleh pembelajaran biasa?

Penelitian ini bertujuan untuk menelaah secara peranan model pembelajaran Van Hiele untuk meningkatkan kemampuan komunikasi matematis siswa SMP.

Berikut ini disajikan definisi operasional variabel yang terlibat dalam penelitian ini.

a. Kemampuan komunikasi adalah kemampuan seseorang untuk menyatakan buah pikirannya dalam bentuk ungkapan kalimat yang bermakna, logis dan sistematis. Adapun indikatornya yaitu:

1) menghubungkan benda nyata, gambar dan diagram, ke dalam ide matematika;

2) menjelaskan ide, situasi dan relasi matematik, secara lisan dan tulisan dengan benda nyata, grafik, dan aljabar;

3) menyatakan peristiwa sehari-hari dalam bahasa atau simbol matematika;

4) mendengarkan, berdiskusi, dan menulis tentang matematika;

5) menyusun konjektur, menyusun argumen, merumuskan definisi dan generalisasi;

b. Model pembelajaran Van Hiele adalah model pembelajaran yang dalam prosesnya terdiri dari lima fase pengenalan, analisis, pengurutan ,berpikir deduksi, dan akurasi.

\section{ISI}

\section{a. Kemampuan Komunikasi Matematis}

Komunikasi matematik merupakan kemampuan matematik esensial. Lebih lanjut Schoen, Bean, dan Ziebarth (Saragih, 2007) mengatakan, komunikasi matematik adalah kemampuan siswa dalam menjelaskan suatu algoritma dan cara unik memecahkan masalah, kemampuan siswa mengkonstruksi dan menjelaskan sajian fenomena dunia nyata secara grafik, kata-kata/kalimat, persamaan, tabel dan sajian fisik atau kemampuan siswa memberikan dugaan tentang gambargambar geometri. Aktivitas ini dapat muncul dengan pembelajaran yang diterapkan pada Van Hiele misalnya pada fase deduksi yaitu pada fase ini mengajak siswa menarik kesimpulan dari halhal yang bersifat umum menuju hal-hal yang bersifat khusus atau membuat generalisasi. Untuk itu model pembelajaran Van Hiele diasumsikan mampu mengembangkan kemampuan komunikasi 
serta kemampuan berpikir kreatif matematis siswa.

Selanjutnya, Polya (1973) menyebutkan bahwa peran guru tidak hanya memberikan informasi saja tetapi juga menempatkan diri sesuai kondisi siswa, dan memahami apa yang terjadi dalam benak siswa yang kemudian memfasilitasi siswa belajar menemukan pengetahuannya dan mengembangkan kemampuan berpikir siswa. Hal ini dimaksudkan bahwa dalam proses pembelajaran selain memberikan informasi juga harus mampu menarik minat siswa untuk terlibat selama proses pembelajaran berlangsung.

\section{b. Model Pembelajaran Van Hiele}

Menurut teori Van Hiele (1999) dalam mengajarkan geometri terdapat lima fase berpikir yang berurutan yang harus dilakukan yaitu fase pengenalan, analisis, pengurutan, deduksi, dan akurasi. Buhari (2011) menambahkan bahwa dengan lima fase berpikir tersebut dapat mengajak siswa untuk berpikir ke tingkat yang lebih tinggi atau dikenal dengan high order thinking.

Erdogan (2009), fase pengenalan merupakan fase menyampaikan informasi yaitu siswa dikenalkan dengan domain yang akan mereka pelajari yang kemudian mengenal contoh dan bukan contoh dari domain tersebut. Fase analisis atau guided orientation yaitu siswa diajak untuk menyelesaikan baik berdiksusi atau individu soal-soal yang harus memiliki hubungan antar konsep. Fase pengurutan atau explicitation merupakan fase mengiring siswa untuk menuliskan relasi atau hubungan antar konsep pada fase analisis ke dalam bentuk gambar atau dengan kata-kata sendiri sesuai dengan topik yang sedang dibahas. Pada fase ini siswa menggunakan ide-ide mereka dalam mengungkap sifat-sifat dari topik yang sedang dibahas. Fase deduksi atau orientation merupakan fase yang mengajak siswa menyelesaikan soa-soal yang lebih kompleks dalam mengungkap dan mengidentifikasikan sifat-sifat dari topik yang dibahas. Terakhir adalah fase akurasi atau integration yaitu fase yang mengajak siswa untuk membuat ringkasan intisari materi yang mereka pelajari pada pertemuan dari fase pertama.

Implementasi pembelajaran geometri dengan teori belajar Van Hiele. Kegiatan belajar geometri dengan van hiele bermaksud untuk melatih kemampuan siswa berdasarkan tahapannya yaitu dimulai dari tahap visualisasi ke tahap analitik. Hal ini dikarenakan fase-fase pembelajaran geometri van hiele menyesuaikan dengan tahapan berpikir anak dengan memperhatikan tingkat kesukaran dimulai dari yang paling mudah samai ke tingkat yang lebih kompleks. Dengan fase-fase tersebut, guru dapat mengetahui perkembangan kognitif anak misalnya guru dapat mengetahui mengapa ada beberapa siswa belum memahami bahwa kubus merupakan balok atau guru dapat mengetahui mengapa masih ada siswa yang beranggapan bahwa persegi panjang bukan persegi.

\section{METODE}

Studi ini dirancang dalam bentuk eksperimen dengan disain pretest posttest control group design yang bertujuan menelaah peranan pembelajaran Van Hiele terhadap kemampuan komunikasi matematis siswa SMP. Sampel ditetapkan secara acak yaitu yang menjadi kelas eksperimen dan kelas kontrol. Tes kemampuan komunikasi matematis siswa masing-masing disusun mengacu pada pedoman penyususunan tes yang baik. Data dianalisis dengan menggunakan uji statistik t.

Dengan demikian desain penelitiannya adalah sebagai berikut (Ruseffendi, 2005):

$$
\begin{aligned}
& \begin{array}{lllll}
\mathrm{A} & : & \mathrm{O} & \mathrm{X} & \mathrm{O}
\end{array} \\
& \mathrm{A}: \mathrm{O} \quad \mathrm{O}
\end{aligned}
$$

Keterangan:

A : pemilihan sampel secara acak kelas

O : tes awal = tes akhir (tes kemampuan koneksi matematis)

$\mathrm{X}$ : perlakuan dengan model pembelajaran Van Hiele

\section{Langkah-Langkah Penelitian}

Untuk melihat langkah-langkah penelitian disajikan pada Tabel 1. sebagai berikut :

\begin{tabular}{|c|c|c|c|}
\hline $\begin{array}{c}\text { Sifat } \\
\text { Kajian }\end{array}$ & Metode & Langkah-Langkah Penelitian & Luaran yang diharapkan \\
\hline $\begin{array}{l}\text { Teoritis, } \\
\text { Empiris }\end{array}$ & $\begin{array}{l}\text { Studi teoritik } \\
\text { dokumentasi }\end{array}$ & $\begin{array}{l}\text { 1. Identifikasi kemampuan } \\
\text { komunikasi, materi ajar, serta } \\
\text { kondisi awal siswa }\end{array}$ & $\begin{array}{l}\text { Data tentang kondisi awal dan } \\
\text { kesulitan belajar siswa }\end{array}$ \\
\hline $\begin{array}{l}\text { Teoritis } \\
\text { Rasional } \\
\text { Empiris }\end{array}$ & $\begin{array}{l}\text { Studi } \\
\text { analisis- } \\
\text { deskriptif }\end{array}$ & $\begin{array}{l}\text { 2. Merancang sampel bahan ajar } \\
\text { dan instrumen untuk } \\
\text { penelitian. }\end{array}$ & $\begin{array}{l}\text { Rancangan bahan ajar dan } \\
\text { instrumen berkenaan dengan } \\
\text { kemampuan komunikasi dan } \\
\text { model pembelajaran Van Hiele } \\
\text { Kontekstual. }\end{array}$ \\
\hline $\begin{array}{l}\text { Teoritis } \\
\text { Rasional } \\
\text { Empiris }\end{array}$ & $\begin{array}{l}\text { Studi } \\
\text { analisis- } \\
\text { deskriptif }\end{array}$ & $\begin{array}{l}\text { 3. Mengujicoba sampel bahan } \\
\text { ajar dan instrumen. }\end{array}$ & $\begin{array}{l}\text { Bahan ajar dan tes kemampuan } \\
\text { komunikasi siswa }\end{array}$ \\
\hline $\begin{array}{l}\text { Rasional } \\
\text { empiris } \\
\text { naturalist }\end{array}$ & \begin{tabular}{|l|} 
Studi \\
analisis \\
deskriptif,
\end{tabular} & $\begin{array}{l}\text { 4. Melaksanakan penelitian } \\
\text { dalam hal melakukan } \\
\text { pembelajaran, analisis data, } \\
\text { analisis pelaksanaan } \\
\text { pembelajaran, laporan, } \\
\text { lampiran dan seminar/ } \\
\text { publikasi hasil penelitian. }\end{array}$ & $\begin{array}{l}\text { Laporan Penelitian dan artikel } \\
\text { untukseminar dan/atau dimuat } \\
\text { dalam jumal } \\
\text { ilmiah ber-issn bertaraf } \\
\text { nasional terakreditasi dan/atau } \\
\text { prosiding yang bertaraf } \\
\text { nasional /internasional. }\end{array}$ \\
\hline
\end{tabular}

Tabel 1. Langkah-Langkah Penelitian 
Data hasil tes (baik postes maupun retensinya) kedua kelompok diolah dengan menggunakan bantuan SPSS 19 dengan langkah sebagai berikut:

a. Menghitung rata-rata dan simpangan baku.

b. Menguji normalitas data sampel.

c. Uji Perbedaan Rata-Rata.

\section{HASIL PENELITIAN}

Pengolahan data tes kemampuan komunikasi matematis didasarkan pada skor pretes dan skor postes. Dari skor-skor tersebut, nilai rata-rata $(\bar{x})$ dan simpangan baku (s) untuk masing-masing kelas dapat diketahui. Berikut ini tabel yang memuat nilai-nilai deskripsi hasil penelitian untuk masing-masing kelas.

\section{Tabel 2. Deskripsi Data Kemampuan} Komunikasi Matematis Siswa

\begin{tabular}{|c|c|c|c|c|c|}
\hline \multirow{2}{*}{ Variabel } & & \multicolumn{2}{|c|}{$\begin{array}{c}\text { Kelas } \\
\text { Eksperimen }\end{array}$} & \multicolumn{2}{c|}{ Kelas Kontrol } \\
\cline { 3 - 6 } & & Pretes & Postes & Pretes & Postes \\
\hline \multirow{2}{*}{$\begin{array}{c}\text { Kemampuan } \\
\text { Komunikasi } \\
\text { Matematis }\end{array}$} & $\mathrm{n}$ & 35 & 35 & 35 & 35 \\
\cline { 2 - 6 } & $\bar{x}$ & 3,31 & 12,54 & 2,83 & 9,77 \\
& $\mathrm{~s}$ & $(20,69)$ & $(78,37)$ & $(17,69)$ & $(61,06)$ \\
\cline { 2 - 6 } & 1,18 & 1,46 & 1,2 & 2,07 \\
\hline
\end{tabular}

Skor Maksimal Ideal : Kemampuan Komunikasi Matematis $=16$

*) Diperoleh dari pembagian antara skor rata-rata dengan skor maksimal ideal dikalikan 100

Berdasarkan deskripsi data mentah pada tabel di atas, diperoleh standar deviasi untuk pretes kemampuan komunikasi matematis kelas eksperimen adalah 1,18 sedangkan kelas kontrol 1,2 , artinya pada kelas kontrol kemampuan awal komunikasi matematisnya lebih menyebar dari pada kelas eksperimen. Selanjutnya, standar deviasi untuk postes kemampuan komunikasi matematis kelas eksperimen adalah 1,48 sedangkan kelas kontrol 2,07, artinya pada kelas kontrol kemampuan komunikasi matematisnya lebih menyebar dari pada kelas eksperimen.

Dari tabel di atas, dapat dilihat bahwa skor ratarata pretes kemampuan komunikasi matematis kelas eksperimen sebesar 3,31 dan kelas kontrol sebesar 2,83, dari kedua data tersebut diperoleh selisih sebesar 0,48. Selisih persentasi rata-rata pretes kemampuan komunikasi kelas eksperimen dan kelas kontrol yaitu 3\% dari rata-rata skor idealnya. Nilai ini menunjukan bahwa nilai kelas eksperimen lebih tinggi dari kelas kontrol dengan selisih data dari kedua kelas tersebut tidak terlalu besar. Dapat diduga bahwa kedua kelas memiliki kemampuan awal komunikasi matematis yang tidak jauh berbeda.

Selanjutnya dari tabel di atas, dapat dilihat bahwa skor rata-rata postes kemampuan komunikasi matematis kelas eksperimen sebesar 12,54 dan kelas kontrol sebesar 9,77, dari kedua data tersebut diperoleh selisih sebesar 2,77. Selisih persentasi rata-rata postes kemampuan koneksi matematis kelas eksperimen dan kelas kontrol yaitu 17,3\% dari rata-rata skor idealnya. Nilai ini menunjukan bahwa nilai kelas eksperimen lebih tinggi dari kelas kontrol dengan selisih data dari kedua kelas tersebut cukup besar. Dapat diduga bahwa kedua kelas memiliki kemampuan komunikasi matematis yang berbeda, dan secara umum kemampuan komunikasi kelas eksperimen lebih baik dari kelas kontrol.

Berdasarkan analisis dari data mentah tabel 2, dapat disimpulkan bahwa secara umum kedua kelas yaitu kelas eksperimen dan kelas kontrol memiliki kemampuan awal komunikasi matematis yang tidak jauh berbeda. Setelah pembelajaran berlangsung, secara umum diketahui kemampuan komunikasi matematis untuk kelas eksperimen mangalami peningkatan yang lebih baik daripada kelas kontrol. Namun demikian, data tersebut belum dapat dipastikan signifikan atau tidaknya, maka dari itu selanjutnya dilakukan uji statistik.

Hasil uji statistik untuk data pretes menunjukan bahwa tidak terdapat perbedaan kemampuan awal komunikasi matematis siswa kelas eksperimen dan kelas kontrol. Sedangkan hasil uji statistik data postes dapat dilihat pada gambar berikut:

\section{Mann-Whitney Test and $\mathrm{Cl}$ :} Eksperimen; Kontrol

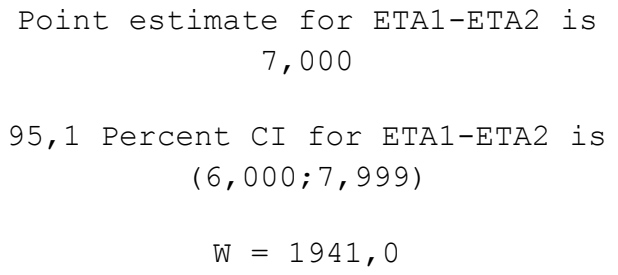

Gambar 1 Hasil Uji Signifikansi Perbedaan Ratarata Nilai Gain Kemampuan Komunikasi Matematis

Dari output pada gambar 1 diketahui nilai Asymp.Sig sebesar 0,000. Karena nilai Asymp.Sig $0,000<0,05$ maka sesuai dengan dasar pengambilan keputusan dalam uji MannWhitney 
dapat disimpulkan bahwa Ho ditolak yang artinya kemampuan komunikasi matematis siswa SMP yang memperoleh model pembelajaran Van Hiele lebih baik daripada yang memperoleh pembelajaran biasa.

\section{KESIMPULAN}

Berdasarkan hasil analisis dan pembahasan serta temuan-temuan yang diperoleh dalam penelitian ini, maka dapat disimpulkan bahwa kemampuan komunikasi matematis siswa SMP yang memperoleh model pembelajaran Van Hiele lebih baik daripada yang memperoleh pembelajaran biasa.

\section{DAFTAR PUSTAKA}

Buhari, B. (2011). Teori Level Van Hiele dalam Pembelajaran Geometri. Tersedia pada http://bustangbuhari.wordpress.com.

Diakses tanggal 28 Juni 2012.

Burger, W.F. \& Shaughnessy, J.M.. (1986). Characterizing the van Hiele Levels of Development in Geometry. Journal for Research in Mathematics Education. 17(I):31-48

Erdogan, et al. (2009). The Effect of the Van Hiele Model Based Instruction on the Creative Thinking Levels of $6^{\text {th }}$ Grade Primary School Students. Educational Science: Theory \& Practice. 9 (1). 181-194

Polya, G. (1973). How to Solve It. A New Aspect of Mathematical Method. New Jersey: Princenton University Press

Ruseffendi, H.E.T. (2005). Dasar-Dasar Penelitian dan Bidang Non-Eksakta lainnya. Bandung: Tarsito

Safrina, K. (2014). Peningkatan Kemampuan Pemecahan Masalah Geometri melalui Pembelajaran Kooperatif Berbasis Teori Van Hiele. (Online). (file:///C:/Documents\%20and\%20Settings/ Mr.\%20Sutia/My\%20Documents/Downlo ads/1333-2528-1-SM\%20(1).pdf , diakses 3 Oktober 2014)

Saragih, S. (2007). Mengembangkan Kemampuan Berpikir Logis dan Komunikasi Matematik Siswa Sekolah Menengah Pertama melalui Pendekatan Realistik. Disertasi UPI. Bandung: Tidak diterbitkan.

Sumarmo, U. (2012). Bahan Belajar Matakuliah Proses Berfikir Matematik. Bandung: Tidak diterbitkan

Suryadi, D. (2004). Landasan Teoritik Pembelajaran Berpikir Matematika.
Tersedia:www.didi_suryadi.staf.upi.edu . html [ 16 Maret 2012]

Usiskin, Z.(1982). Van Hiele Levels and Achievement in Secondary School Geometry. (Final report of the Cognitive Development and Achievement in Secondary School Geometry Project.) Chicago: University of Chicago. (ERIC Document Reproduction Service No. ED220288)

Van Hiele, P.M. (1999). Developing Geometric Thinking Through Activities That Begin With Play. Teaching Children Mathematics. (pp 310-316). Reston VA: National Council of Teachers of Mathematics 